\title{
The Influence of the Corporate Management Commitment in Building Organizational Culture and Cross-Funtional Integration to Improve Company's Business Performance
}

\author{
Zeplin Jiwa Husada Tarigan*, Widjojo Suprapto, Sautma Ronni Basana \\ Petra Christian University, Surabaya, East Java, Indonesia. \\ * Corresponding author. Email: zeplin@peter.petra.ac.id \\ Manuscript submitted March 1, 2017; accepted June 2, 2017. \\ doi: 10.17706/ijeeee.2017.7.3.202-211
}

\begin{abstract}
Integration across management functions is a kind of an interaction that facilitates the coordination of various management function activities so that they can cooperate effectively and efficiently to reach the company's goals. The cross-function integration brings positive impacts to the company if it is supported by the top management, the organizational culture, and the strong teamwork to reach the company performance.

This research has two main purposes. The first aim is to investigate whether the management commitment can bring impact to the forming of organizational culture and good teamwork in building the management function integration. The second aim is to investigate whether the cross-functional integration brings a positive impact to the company performance.

The questionnaires are distributed among 94 manufacturing companies in East Java Indonesia. The data are processed with PLS. The result shows that there is a positive influence between the management commitment and the organizational culture formation. There is also a positive influence between the management commitment and the effective teamwork formation. Finally, it gives an impact to the company performance.
\end{abstract}

Key words: Management commitment, organization culture, ERP system and business performance.

\section{Introduction}

The global market has changed the paradigm of many business leaders to conduct their management in producing manufacturing goods in order to maximize the profit. The globalization creates competitions among companies from the same region to different countries. Nowadays, the companies are thrived to build networks with other companies to collaborate in creating mutual benefits. Most companies implement a supply chain management system to integrate information technology within the internal company to improve the communication speed. In companies that do not integrate their information technology system, each management function, such as marketing, production, purchasing, quality control, and accounting, use different information systems which store and collect information solely for the sake of each business function [1].

A cross-function integration is a form of relationship that facilitates the coordination among various management functions so that they can cooperate together to reach the company's goals efficiently and effectively. This integration is not only limited to the internal management functions but also to other 
different companies that are connected by the supply chain management [2]. This cross-function integration also brings many positive impacts to the company, yet the process of this integration is not easy. Even after setting up the integration, many companies are not performing as expected. Kocoglu et al. [3] States that the head of the supply chain management needs total supports from all functional managers in order to manage the integrating process. The same article also reveals that all managers need to consider the supply chain management performance as a supply chain integration that focuses on the relation between the company and the supply chain members like suppliers and customers.

A research by Flynn et al. [4] in manufacturing industries in China finds out that the internal integration and the external integration, especially with the consumers, have a significant positive impact to the operational performance. A research by Al-Gahtani et al. [5] finds a strong influence between the national culture and the usage of information system technology. Another research shows that there are only several aspects of the national culture which have a strong influence to the integration of the information system [6]. However, the result from a research by Sornes et al. [7] in fact shows no influence from the national culture to the usage of information system.

An organization needs to coordinate different procedures and business conducts exposed by various management functions and departments and synchronize them in a system where sharing knowledge is mandatory by the organization [8]. A research by Choo et al. [9] confirms a significant influence from an organizational culture that is related to information, such as sharing, proactive, informality, and transparency, to the usage of the information system and the result of the integrated usage. The commitment of the top management has formed the organizational culture that has been adopted by the project team to integrate cross-function management so that the integration can improve the organizational performance which is reflected through the performance of the supply chain management.

The main focus of this research is to investigate how a company manages to build and synchronize its function across various departments. This synchronization will become the company's culture which integrates various data from different departments into ERP system. In East Java, Indonesia, many companies still rely on their departmental goals, not the organization as the whole integrated goals. The companies are reluctant to switch from the manual system into the ERP system totally, because they are operating these two systems simultaneously. When the companies manage to integrate the data from all management functions, the data will be more accurate for the top management to make business decisions, and the company's performance will improve.

\section{Theoritical Background}

\subsection{Supply Chain Managment}

Supply chain management (SCM) is an organizing and controlling of a company's supply chain, in which the supply chain is the whole network of the company or organization which produces good or services to the end consumers. SCM focuses on the relationship between a company with the network of consumers and suppliers. It means the activities of the company cover a wide range from the consumers to the suppliers. SCM is a system of organization, human resources, technology, work activities, and information about material movements from the suppliers to consumers [10]. SCM is also a system that is designed to integrate and relate suppliers to consumers. According to Fawcett et al. [11], a good supply chain performance is marked by a unique product and service, a fast R\&D cycle, good quality, competitive costs, a shorter ordering cycle, a flexible customer service, a good delivery performance, good asset management, good cash flows, and a good relationship in the supply chain. Eriksson [12] states that a company needs to consider any supply chain problems in order to support the corporate strategies through its integration. The implementation of supply chain integration has to be able to synchronize the activities and technology 
used by the company which covers the management functions on the right time with the right human power. All companies that have implemented SCM must automatically have implemented cross-function integration because SCM requires the usage of the integrated information technology.

\subsection{Commitment Management}

The commitment given by the top management to a business system is in terms of support and attention to the process, such as providing time to help handle on-going problems. The commitment can also be the allocation of resources needed to run the system, such as human resources, funding, autonomy, authority, training, facilities, and policies. The commitment is also very important to the cross-function integration because the top management can shape the perception, dedication, and self-empowerment from the project team. The top management needs to provide a vast range of information and knowledge about main issues for each level of the integration process. A research by Lee et al. [13] reveals that the top management commitment can increase the effectiveness on sharing knowledge within an organization so that it will ease the implementation of the cross-function integration. Perera and Jayasunandra (2013) [14] mention that the top management commitment can be measured by the availability of adequate resources, the existence of managerial control, and the credibility and trust given by the management.

\subsection{Organizational Culture}

Culture is a collective program that exists inside human mind and differentiates a group of men with other groups [15]. Meanwhile, an organizational culture is a culture that are shaped by several factors, such as country of origins, types of industries, types of duties in any organization, man power in the organization, and the existing information technology. This culture affects how people work in the organization [11]. The organizational culture can become an instrument to increase the business performance by providing the competitive advantage to win the competition. Besides, the organizational culture can also be used to control and organize the attitude of employees [16]. This research is following the theory of Detert et al. [17] who have established the values in evaluating the influence of the organizational culture to the employees, including the key users, in supporting the ERP implementation successfully: the culture based on accountability and rationality, the culture that motivates, the culture based on work oriented, and the culture that focuses on the company. A research by Lee et al. [13] describe that the organizational culture can help understand the company business process and share knowledge among departments so that the implementation of the technology can run more effectively.

\subsection{Cross-Functional Integration and ERP System}

Cross-functional integration is one type of integration that connects managerial functions within a supply chain. A cross-function integration creates a relationship to facilitate coordination among activities from various management functions so that they can cooperate effectively to reach the objectives of the company or the supply chain. This cross-function integration can connect not only the internal functions or departments, but also among different companies to create supply chains that are integrated, responsive, efficient, and well managed. Olivia and Watson [18] states that the cross-function integration may provoke conflicts among various departments; therefore clear standard operating procedures are needed.

Flynn et al. [4] proposes several variables that can be used to measure the internal integration within the supply chains. Those variables can be classified into four main categories, such as the availability of integrated data, the existence of regular meetings among departments, the availability of real-time connection among departments, and the existence of real-time logistic/inventory search engine. These four indicators are used in this research to measure cross-function integration variables.

Narimani et al. [19] say that ERP is a system that integrates business functions internally to provide 
information to increase the business performance. One of the values in implementing cross-function integration or ERP is always related to the financial performance of the company if it is implemented effectively [20]. According to Zhang and Okorafo [21] supply chain integrations are systems that provide an infrastructure to integrate the business process in a company with the aim to reduce costs and to increase quality, especially through accurate and fast information about the business. The integrated data under the ERP system will help the top management make business decisions. The indicators for this research on ERP implementation are user's satisfaction, quality information, reporting data software sustainability, and system quality [31].

\subsection{Business Performance}

A business performance is the accomplishment of one business process or task to reach the company's objectives that is measured by the existing standard. A research conducted by Baske and Seuring [22] reveals that the company performance obtained from a supply chain can sustain the company. Mostly, the performance is the working result that becomes the competitive advantage of a company to compete with other companies. A research by Mathivathanan et al. [23] identify several elements for the company performance, among others are company profitability, company flexibility, customer satisfaction, and employee satisfaction. Karabulut [24] conducts a research on manufacturing companies in Turkey using Balanced Scorecard to measure the performance and uses the criteria as follows: the company financial performance, the customer satisfaction performance, the internal process performance, and the learning and growth performance.

\subsection{Hypothesis}

Based on theoritical there are several hypothesis constructed as follows:

H1: the top management commitment influences the cross functional integration.

$\mathrm{H} 2$ : the top management commitment influences the organizational culture.

H3: the top management commitment influences the ERP system.

$\mathrm{H} 4$ : the cross functional integration influences the organizational culture.

H5: the current organizational culture affects the ERP system.

H6: the ERP system affects the company performance.

H7: the current organizational culture affects the company performance.

\section{Research Metodology}

This study is examining the effect of one variable to another variable for hypothesis test which is called causal research [25]. This is a quantitative research with the primary data collected by distributing questionnaires directly to the manufacturing companies in East Java Indonesia. The population for this research is companies that are registered in the East Java Industrial Department and have implemented the ERP system for at least one year. To obtain the 67 companies, this research is using the purposive sampling method. From the 110 questionnaires distributed, there are only 98 returned questionnaires, with only 94 valid questionnaires (the response rate of 85.45). The measuring scale is using the Likert scale, with the intervals from one to five. This research uses numerical data to illustrate the reality of the relationship among existing variables. For the data analysis method, this research is using SEM (Structural Equation Modeling) based on PLS (Partial Least Square), with the help of a software Smart PLS [26].

\section{Finding and Discussion}

The respondents of this research are employees of manufacturing companies that have a certain role related to the implementation of cross-function integrations summarized by ERP (Enterprise Resource 
Planning) and have an authority in the business change process. The selected respondents are from various departments which are related to running and changing the ERP systems in manufacturing companies, such as from the accounting department who perform the CO module, the finance department with the FI module, the production and planning department who are in charge of carrying out the PO module, and several other departments that are related to the integration of cross-function departments within the company. From 100 returned questionnaires, there are 94 questionnaires that can be further processed with a response rate of $94 \%$. To test the hypothesis and generate an appropriate model, PLS is used to analyze the data with the calculation process assisted by Smart PLS software. Testing the outer model for this research, the indicators from variables can be considered as the variable measuring instrument.

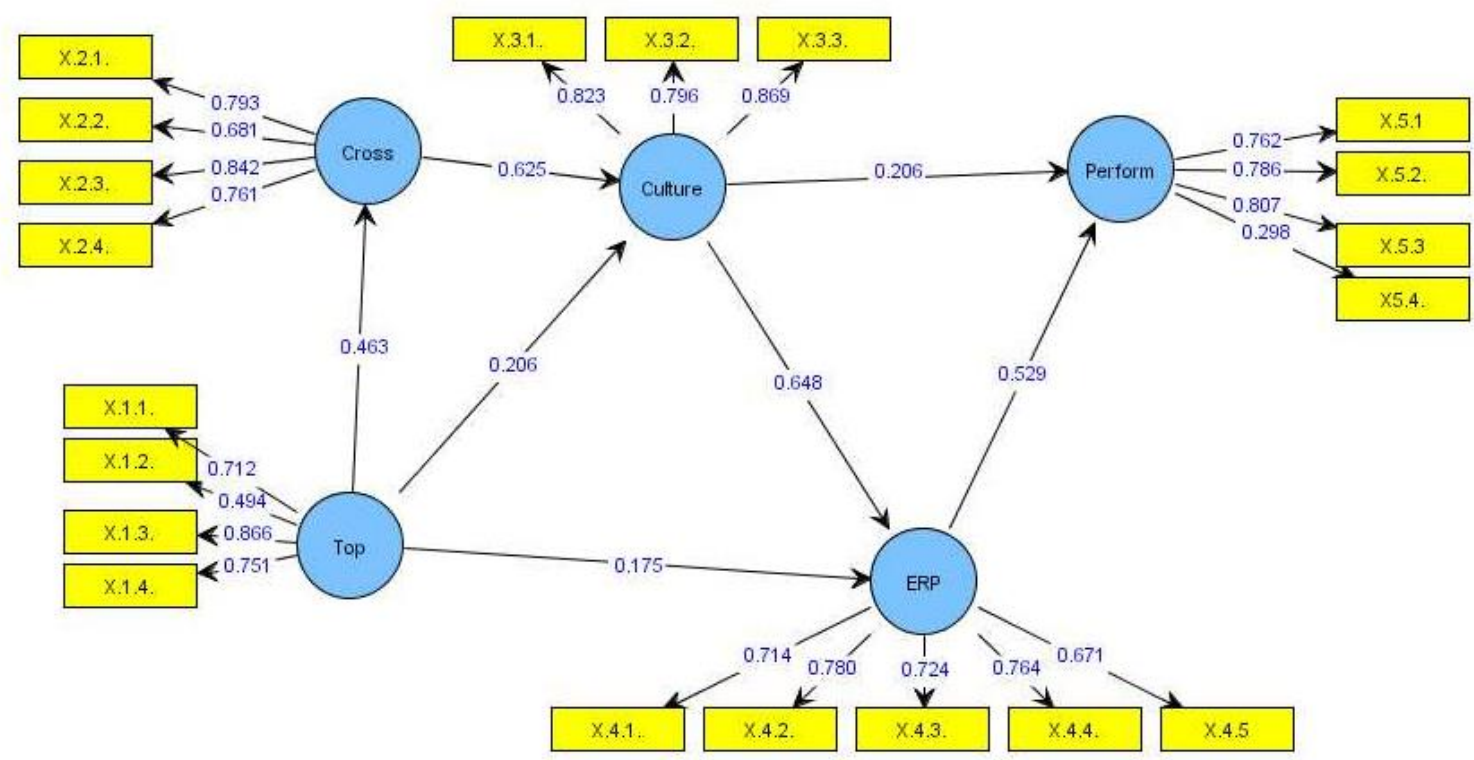

Fig 1. The result of the research model.

Table 1. The Inner Weight

\begin{tabular}{|c|c|c|c|c|}
\hline & $\begin{array}{c}\text { original sample } \\
\text { estimate }\end{array}$ & $\begin{array}{c}\text { mean of sub } \\
\text { samples }\end{array}$ & $\begin{array}{c}\text { Standard } \\
\text { deviation }\end{array}$ & T-Statistic \\
\hline Culture -> Perform & 0.206 & 0.205 & 0.082 & 2.049 \\
\hline ERP-> Perform & 0.529 & 0.561 & 0.160 & 3.307 \\
\hline Top -> Culture & 0.206 & 0.203 & 0.077 & 2.682 \\
\hline Cross -> Culture & 0.625 & 0.619 & 0.060 & 10.500 \\
\hline Culture-> ERP & 0.648 & 0.642 & 0.091 & 7.080 \\
\hline Top - ERP & 0.175 & 0.188 & 0.095 & 1.851 \\
\hline Top -> Cross & 0.463 & 0.472 & 0.077 & 6.049 \\
\hline
\end{tabular}

Based on the results of the data processing in Table 1., it is found that the first hypothesis is accepted with the result of the top management commitment has a positive and significant influence on cross functional integration as. 463 with the t-statistic value 6.049 (t-statistic $>1.96$; significant $\alpha=0.05$ ). This research shows that the top management commitment, built by the leader credibility with the loading factor of 0.866 , and the trust with the loading factor of 0.751 , are able to increase the cross functional integration. This cross functional integration synchronizes various data, so that the connected data are useful for the top management to make decision promptly. This research support a research by Lambert et al. [27] that states the accurate managerial decision making needs a support from the cross functional integration. Joshi [28] also states that the commitment of the top management and the competence of the work team decide the good performance of the cross functional integration in any company. However, the result of this research is 
different from the research by Akintoye et al. [29] in a construction industry in England which shows no correlation between the commitment of the top management and the cross functional integration.

The second result of the top management commitment has a positive and significant the organizational culture as .206 with the t-statistic value of 2.682 (t-statistic $>1.96$; significant $\alpha=0.05$ ). The top management commitment, built through credibility and trust, to the ERP implementation key users can create awareness about the ERP system and can benefit the company as the ERP system can be implemented entirely in the company. The result supports Mashari et al. [30] that states the top management commitment can give beneficial impacts to the cultural and structural changes in the organization. This study also supports the Zang et al. [31], who suggest that an organizational culture, in this case employee professionalism to their duty and responsibility, brings positive influence because it can speed up the ERP implementation process.

The third hypothesis is accepted as the top management commitment has a positive but no signfiicant impact to ERP systems at .175 with the t-statistic value of 1.851 (t-statistic $<1.96$; significant $\alpha=0.1$ ). The credibility and trust from the top management to the key users, however, cannot support the implementation of ERP, because the ERP system needs direct activities among departments. Besides, the credibility and trust are values, not practical activities. This research supported Turkulainen [32] who finds if the system is only at the manufacturing level, it will not significantly influence the company's cross function integration.

The fourth hypothesis can be accepted as the company's cross function integration brings a positive and significant impact to the organizational culture as .625 with the t-statistic value of 10.500 (t-statistic > 1.96; significant $\alpha=0.05$ ). The function of across departmental integrations brings impacts to a company in terms of mutual understanding and communication to form collaborations among departments which will become the unique organizational culture in a manufacturing industry.

The fifth hypothesis can be accepted the current organizational culture has a positive and significant the ERP systems as .648 with the t-statistic value of 7.080 ( $t$-statistic $>1.96$; significant $\alpha=0.05$ ). This research is in accordance to the research by Park et al. [33] which states the sharing knowledge will increase the understanding and usage of ERP comprehensively. This research also supports the research by Zang et al. [31] which reveals the positive correlation between the proper data input as a good organizational culture and the implementation process of the ERP system. This research is supported Jones et al. [34] who states that the organizational culture brings a positive impact to the ERP teamwork in sharing knowledge.

The sixth hypothesis can be accepted the ERP system affects the company performance at .529 with the t-statistic value of 3.307 (t-statistic $>1.96$; significant $\alpha=0.05$ ). This result supports the research of Calisir and Calisir [35] on 24 companies that shows the increasing company performance due to the ERP system in providing quick and accurate information. This research is also supporting Sun et al. [16] who claim the ERP systems in reducing the operational costs. A research by Amoako and Gyampah [36] reveals that the ERP system surrenders a positive significant impact to the performance in serving the customers. However, this different from a research by Bradford and Florin [37] that state a negative impact of ERP technology to the organizational performance due to the limited interconnection and validity of the software.

The seventh hypothesis can be accepted as the current organizational culture affects the company performance at .206 with the t-statistic value of 2.049 ( $\mathrm{t}$-statistic $>1.96$; significant $\alpha=0.05$ ). This research is in accordance to Gunasekaran et al. [38] that states information system can directly influence the performance of supply chain (PSC). This research is in accordance to Jones et al. [34] who claim sharing knowledge enabling to increase the company performance through the corporate culture. This research also supports Wang et al. [39] who state learning commitment in a company surrendering a positive impact to the work commitment so that increasing the performance. The future research is comparing the test of the 
difference in the implementation of pre and post ERP in a company. It also observes the dual systems (manual and ERP system side by side) during the implementation stage of the company. It takes time and strong work ethic in building cross functional to make a habitual activity for the employees so it needs thorough investigations.

\section{Conclusion}

Based on the results of the data processing and analysis, there are several conclusions as follows:

1) The commitment of the top management is able to form cross functional integrations in manufacturing companies in East Java

2) The commitment top management of the organization is able to build a good organizational culture for manufacturing companies in East Java.

3) The commitment of the top management is not able to form ERP systems in manufacturing companies in East Java

4) The cross functional integration is able to influences the organizational culture in manufacturing companies in East Java

5) The current organizational culture affects the ERP system in manufacturing companies in East Java.

6) The ERP systems implemented by the manufacturing companies in East Java are able to improve the financial performance.

7) The organizational culture is able to implement cross-function integrations that bring impacts on the company financial performance.

\section{References}

[1] Toni, A. F. D., Fornasier, A., \& Nonino, F. (2015). The impact of implementation process on the perception of enterprise resource planning success. Business Process Management Journal, 21(2), 332-352.

[2] Kim, H., Kim, Y. G., \& Park, C. W. (2010). Integration of firm's resource and capability to implement enterprise CRM: A case study of a retail bank in Korea. Decision Support Systems, 48, 313-322.

[3] Kocoglu, I., Imamoglu, S. Z., Ince, H., \& Keskin, H. The effect of supply chain integration on information sharing: enhancing the supply chain performance. Procedia Social and Behavioral Sciences 24, 1630-1649.

[4] Flynn, B. B., Huo, B., \& Zhao, X. (2010). The impact of supply chain integration on performance: A contingency and configuration approach. Journal of Operations Management, 28, 58-71.

[5] Al-Gahtani, S. S., Hubona, G. S., \& Wang, J. (2007). Information technology (IT) in Saudi Arabia: Culture and the acceptance and use of IT. Information and Management, 44, 681-691.

[6] Silvius, A. J. G., Haes, S. D., \& Gremberge, W. V. (2006). Exploration of culture influences on business and IT alignment. Retrieved November, 23, 2013, from Universiteit Antwerpen, ITAG Research Institute Web site.

[7] Sornes, J., Stephens, K. K., Saetre, A. S., \& Browning, L. D. (2004). The reflexivity between ICTs and Business Culture: Applying hostfede,s theory to compare Norway and the United States. Informing Science Journal, 7, 1-30.

[8] Rebelo, M. F., Santos, G., \& Silva, R. (2016). Integration of management system: Toward a sustained success and development of organizatitions. Journal of cleaner production, 127, 96-111.

[9] Choo, C. W., Bergeron, P., Detlor, B., \& Heaton, L. (2008). Information culture and information use: An exploratory study of three organizations. Journal of the American Society for Information Science and Technology, 59(5), 792-804. 
[10] Agrell, P. J., \& Marbini, A. H. (2013). Frontier-based performance analysis models for supply chain management: State of the art and research directions. Computers \& Industrial Engineeringg, 66, 567-583.

[11] Fawcett, S. E., Magna, G. M., \& McCarter, M. W. (2005). The effect of people on the supply chain world: Some overlooked issues. Human Systems Management, 24(3), 197-208.

[12] Eriksson, P. E. (2015). Partnering in engineering projects: four dimensions of supply chain integration. Journal of Purchasing \& Supply Management, 21, 38-50.

[13] Lee, J. C., Shiue, Y. C., \& Chen, C. Y. (2016). Examining the impacts of organizational culture and top management support of knowledge sharing on the success of software process improvement. Computers in Human Behavior, 54, 462-474.

[14] Perera, M. L. A., \& Jayasundra, C. C. (2013). Impact of IT/IS management commitment on strategic information system planning: A study of selected commercial bank in Colombo District Sri Lanka. Academy of Contemporary Research Journal, 7(4), 161-170.

[15] Hofstede, G. (1997). Cultures and organization: Software of the Mind. New York:McGraw Hill.

[16] Sun, A. Y. T., Yazdani, A., \& Overend, J. D. (2005). Achievement assessment for enterprise resources planning (ERP) system implementation based on critical success factors (CFS). International Journal Production Economics, 98, 189-203.

[17] Detert, J. R., Schroeder, R. G., \& Mauriel, J. J. (2000). A framework for linking culture and improvement initiatives in organizations. Academy of Management Review, 25(4), 850-863.

[18] Olivia, R., \& Watson, N. (2011). Cross-functional alignment in supply chain planning: A case study of sales and operations planning. Journal of Operations Management, 29, 434-448.

[19] Narimani, M., Tabaeian, E., Khanjani, M., \& Soltani, F. (2014). The impact of organizational citizenship behavior on enterprise resource planning success the mediator role of TQM. International Journal of Quality \& Reliability Management, 31(1), 53-65.

[20] Sohn, S. Y., Kim, H. S., \& Moon, T. H. (2007). Predicting the financial performance index of technology fund for SME using structural equation model. Expert Systems with Application, 32, 890-898.

[21] Zhang, H., \& Okoroafo, S. C. (2015). Third-party logistic (3PL) and supply chain performance in the chinese market: A conceptual framework. Engineering Management Research, 41(1), 38-48.

[22] Baske, P., \& Seuring, S. (2014). Putting sustainable into supply chain management. Supply Chain Management International Journal, 19(3), 322-331.

[23] Mathivathanan, D., Govindan, K., \& Haq, A. N. (2017). Exploring the Impact of dynamic capabilities on sustainable supply chain firm's performance using grey-analytical hierarchy process. Journal of Cleaner Production, 147, 637-653.

[24] Karabulut, A. T. (2015). Effects of innovation types on performance of manufacturing firms in Turkey. Procedia Social and Behavioral Sciences, 195, 1355-1364.

[25] Cooper, D. R., \& Schindler, P. S. (2008). Business Research Methods 10e. McGraw-Hill/Irwin.

[26] Ghozali, I. (2006). Structural Equation Modeling, Metode Alternatif dengan Partial Least Square. Badan Penerbit Universitas Dipenegoro, Semarang.

[27] Mashari, M. A., Mudimigh, A. A., \& Zairi, M. (2003). Enterprise resources planning: A taxonomy of critical factors. European Journal of Operational Research, 146, 352-364.

[28] Zang, Z., Lee, M. K. O., Huang, P., Zhang, L., \& Huang, X. (2005). A framework of ERP systems implementation success in China: An empirical study. International Journal Production Economics, 98, 56-80.

[29] Akintoye, A., McIntosh, G., \& Fitzgerald, E. (2000). A survey of supply chain collaboration and management in the UK construction industry. European Journal of Purchasing \& Supply Management, 6, 
159-168.

[30] Mashari, M. A., Mudimigh, A. A., \& Zairi, M. (2003). Enterprise resources planning: A taxonomy of critical factors. European Journal of Operational Research, 146, 352-364.

[31] Zang, Z., Lee, M. K. O., Huang, P., Zhang, L., \& Huang, X., (2005). A framework of ERP systems implementation success in China: An empirical study. International Journal Production Economics, 98, 56-80.

[32] Turkulainen, V. (2008). Managing cross-functional interdependencies. Retrieved November 22, from Helsinki University of Technology Department of Industrial Engineering and Management website: http://lib.tkk.fi/Diss/2008/isbn9789512295333

[33] Park, J. H., Suh, H. J., \& Yang, H. D. (2007). Perceived absorptive capacity of individual users in performance of enterprise resources planning (ERP) usage: The case for Korean firms. Information \& Management, 44, 300-312.

[34] Jones, M. C., Cline, M., \& Ryan, S. (2006). Exploring knowledge sharing in ERP implementation: An organizational culture framework. International Journal Decision Support Systems, 41, 411-434.

[35] Calisir, F., \& Calisir, F. (2004). The relation of interface usability characteristics perceived usefulness, and perceived ease of use to end-user satisfaction with enterprise resources planning (ERP) systems. Computer in Human Behavior, 20, 505-515.

[36] Amoako, K., \& Gyampah. (2004). ERP implementation factors a comparison of managerial and end user perspectives. Business Process Management Journal, 10(2), 171-183.

[37] Bradford, M., \& Florin, J. (2003). Examining the role of innovation diffusion factors on the implementation success of enterprise resources planning systems. International Journal of Accounting Information System, 4, 205-225.

[38] Gunasekaran, A., Patel, C., \& Tirtiroglu, E. (2001). Performance measures and metrics in a supply chain environment. International Journal of Operation \& Production Management, 21(1/2), 71-87.

[39] Wang, E., Ying, T. C., Jiang, J., \& Klein, G. (2006). Group cohesion in organizational innovation: An empirical examination of ERP implementation. Information and Software Technology, 48, 235-244.

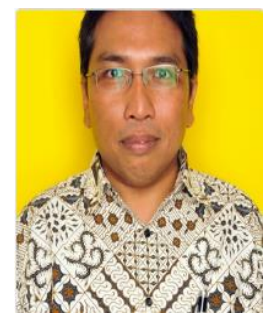

Sautma Ronni Basana was born in 1964. He obtained his bachelor degree in economics from Universitas Brawijaya, Malang, Indonesia, and his master's degree in economics from University of Indonesia, Jakarta, Indonesia. At the moment, he is preparing his dissertation for his doctorate degree in economics in University of Brawijaya, Malang, Indonesia. $\mathrm{He}$ is an associate professor on financial management in Petra Christian University, Surabaya, Indonesia. His research interests are financial management and ERP.

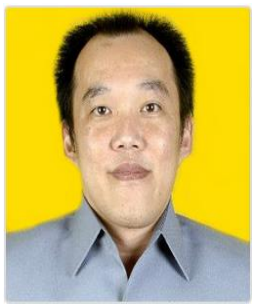

Widjojo Suprapto was born in 1967. He obtained his bachelor degree in English literature from Petra Christian University, Surabaya, Indonesia, and his master's degree in hospitality management from University of Nevada Las Vegas, USA. He devotes his experiences in the world of tourism, hotel, and restaurant. He is also a full time faculty member in Petra Christian University, Surabaya, Indonesia, teaching in the Business Management Program. His research interests are hospitality supply chain management and Chinese family business. 
Zeplin Jiwa Husada Tarigan was born in 1974. He obtained his bachelor degree in electric and telecommunication engineering, and the master's degree in industrial management from Sepuluh Nopember Institute of Techonolgy. He obtained his doctorate degree from University of Brawijaya, Malang, Indonesia. He has experienced as a manager in PPIC and BPO PP SAP R/3 in some manufacturing industries. At the moment, he is a full time faculty member at Petra Christian University, teaching in the program magister management or master's program. His research interests are ERP and operation management. 